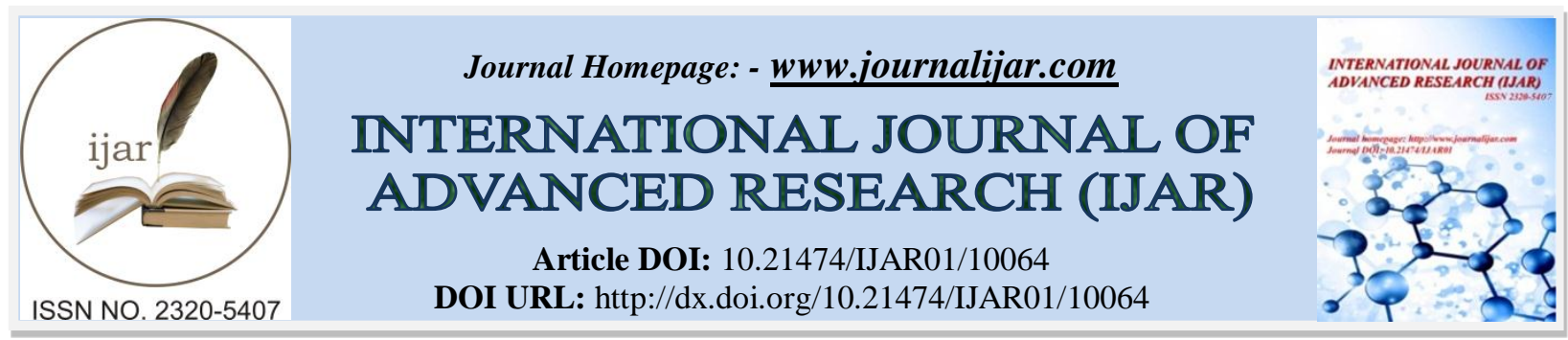

RESEARCH ARTICLE

\title{
PRACTICALITY OF SCIENCE TEACHER'S BOOK WITH THE THEMES OF BLOOD FLUID USING LEARNING OF INTEGRATED CONNECTED TYPE 21ST CENTURY LEARNING
}

\author{
Riza Helfira ${ }^{1}$, Tri Anidya Putri ${ }^{2}$, Ratnawulan ${ }^{3}$ and Syafriani ${ }^{3}$
}

1. Teacher in Junior High School Number 1 Sasak Ranah Pasisie, Pasaman Barat-26366, Sumatera Barat, Indonesia

2. Postgraduate physics education students, Universitas Negeri Padang Jl. Prof. Dr. Hamka Air Tawar Barat Padang-25131, Indonesia

3. Lecturer of Master Degree Program of Physics Education, Universitas Negeri Padang Jl. Prof. Dr. Hamka Air Tawar Barat Padang-25131, Indonesia

\section{Manuscript Info}

\section{Manuscript History}

Received: 12 September 2019

Final Accepted: 14 October 2019

Published: November 2019

Key words:-

Practicality, Teacher's Book, connected type, 21st Century Learning.

\begin{abstract}
Teacher's book is a guide for teachers in carrying out learning as well as guidelines for the use of student books. One way to find out the quality of the teacher's book that was developed was by the practicality test. The purpose of this study is to determine the practicality of Integrated Science teacher books on the theme of blood fluid using integrated learning integrated type learning in the 21 st century. The type of research used is Plomp model development research, practicality is carried out at the development stage. The research instrument used was the practicality assessment instrument sheet. The practicality assessment instrument sheet was filled out by several junior high school science teachers in West Pasaman. Data analysis is descriptive analysis with a Likert scale and practicality is calculated as a percentage. The results of the practicality analysis state that the teacher book that has been developed has very practical criteria. From the results of the analysis it can be concluded that the Tepadu Science Teacher's book with the theme of blood fluid using integrated learning integrated type 21 st century learning is very practical to be used in the learning process.
\end{abstract}

Copy Right, IJAR, 2019,. All rights reserved.

\section{Introduction:-}

Natural science is a systematic and comprehensive science, not a partial science between Physics, Biology, and Chemistry. Therefore the learning of natural science must be carried out in an integrated manner. Integrated natural science is packaged by combining, integrating and integrating natural science learning in one integrated unit [1]. Learning that is done in an integrated manner will make students learn about nature and the phenomena that occur in it as a whole and find concepts in life.

Integrated learning will make learning for students more meaningful. This is because learning is essentially not just memorizing concepts or facts, but trying to connect these concepts to produce a more complete understanding, so the concepts learned will be well understood and not easily forgotten [2]. Integrated learning is a learning method that involves several fields of study to provide meaningful experiences to students [3].

Corresponding Author:-Ratnawulan.

Address:- Lecturer of Master Degree Program of Physics Education, Universitas Negeri Padang Jl. Prof. 
The type of integrated learning developed in the teacher's book is the connected type. integrated learning connected model is a learning model that connects one concept with another concept, one topic with another topic, one skill with another skill, even ideas learned in one semester with ideas learned in the next semester in one field of study [ 4]. Integrated type connected learning makes it easier for students to find connections [5]. The connected types in the teacher's book are presented on the concept map and the elaboration of the material, where learning materials are at the same time examined based on the fields of Physics, Chemistry, and Biology.

Determination of the theme is very important to do in integrated learning activities. The theme is the main thoughts or ideas that are the subject of discussion. The theme is a tool or container to put forward various concepts to students in their entirety [6]. Integrated learning will occur if an authentic event or exploration of a topic or theme becomes a controller in learning activities, so that students learn as well as the process and content of several subjects simultaneously [2]. Based on the quote, it can be concluded that the theme is a tool used as a unifying material that is diverse from various subject matter in integrated learning. The theme chosen in the development of this book is the theme of blood fluid, because blood fluid is close to the lives of students.

Besides natural science as a science that can lead to new things in the form of technology. Science and technology are the cornerstone of the 21st Century, so it demands human resources to master various forms of skills. In other words, various skills in the frame of science and technology that need to be mastered by human resources, become a key word for a nation to participate in the world arena. The role of schools in addressing the development of the $21 \mathrm{st}$ century can be done by practicing the skills needed in facing the challenges of the 21 st century in learning.

One of the skills needed in the 21st century is higher order thinking skills that learners need to face global challenges [7]. Graduates of today need to become proficient in 21st century workplace skills as to meet the challenges of this era. The respective skills are critical thinking and problem solving, communication, collaboration, creativity and innovation [8]. With the attention of establishing a globally competitive personality, the 21 st century learning framework suggest the key subject to be taught in the classroom, themes that come across the subject, the 4Cs (critical thinking, communication, collaboration, creativity) to be imposed in the learning and innovation skills, life and career skills to be instilled and how information, media, and technology skills should be imparted to our current "tech-savvy" learners [9]. The partnership for 21st century skills identifies 21 st century skills as critical thinking and problem solving, communication, collaboration, and creativity and innovation- more commonly known as the $4 \mathrm{C}$ skills [10]. The other skills that learners have to face to challenge the 21 st century is to have a strong mentality [7]. In order to have a strong mentality in facing the challenges of the 21 st century, the religious character must be attached to the students themselves [7]. Based on the explanation above, the 21st century skills that need to be trained for students are higher order thinking skills, critical thinking and problem solving, communication, collaboration, creativity and innovation, and religious character.

The reality that exists in the field of teachers who teach science does not have an integrated science education background. The existing integrated science teachers are mostly inexperienced, untrained and in some cases, not eligible for the work they do [11]. Most teachers have not practiced the integrated science learning model and have difficulty in designing Integrated Science learning in learning in terms of physics, biology and chemistry [12]. This has an impact on the learning outcomes of students who are still having difficulty instilling integrated concepts between physics, biology and chemistry. In addition, science learning in schools has not optimally integrated 21 st century skills. Whereas the 2013 curriculum expects students to have skills that are appropriate to the times.

To overcome these problems, the teacher in teaching uses the teacher's book. Teacher's book is a guide for teachers in carrying out learning as well as guidelines for the use of student books. The teacher textbook can serve as; guidance on the use of student books, reference learning activities in the classroom, an explanation of the methods and learning techniques used in the learning process [7]. The teacher's book is live documents that are constantly being fixed, updated, and updated in accordance with the dynamics of needs and changing times. The teacher's book talks about the process issues in the classroom, which is used as a guide for the use of the student's book. Therefore the teacher must first learn the information from the teacher's book [13]. The teacher book outlines the minimum effort students must make to achieve the expected competence [14]. To address the challenges of the 21st century, teachers' books should integrate the skills needed in 21st century learning [7]. Book of teachers should integrate concepts, ideas and topics and skills so that learners fully understand the competencies by applying integrated learning [7]. 
Based on the results of the preliminary study analysis by distributing questionnaires to a number of teachers who teach junior high school natural science in West Pasaman, it turns out that the teacher book used is not optimal in carrying out integrated learning and integrating 21st century learning. Based on this, an integrated science teacher book was developed with the theme of blood fluids using integrated type learning integrated 21st century learning. The structure of the teacher book that was developed refers to the 2013 revised grade VIII IPA (science) teacher curriculum book from the Ministry of Education and Culture which consists of covers, general instructions, and specific instructions.

General guidelines consist of integrated science and learning; assessment of science learning and follow-up; integrated type connected learning, 21st century learning and the interconnectedness of integrated learning syntax with scientific approaches, and 21st century skills; and mapping of connected blood fluid theme material. The specific instructions section consists of several sub themes. Each sub-theme consists of a cover, concept map, introduction, learning activities, assessment and competency achievement grid, answer key, enrichment material, and project assignments. The introduction consists of basic competencies, indicators of achievement of competencies and learning objectives, time and material allocation.

To find out the quality of teacher's books, one of them is a practicality test. Practicality tests conducted on teacher books that are valid. practicality shows the level of ease of use and implementation which includes the cost and time in the implementation and management and interpretation of the results [15]. Practicality is an integral part of the concept of test usefulness and affects many different aspects of an examination. It can be defined as the extent to which an examination is practicable in terms of the resources necessary to produce and administer it in its intended context and use [16]. Based on this opinion the practicality of the teacher's book that was developed consisted of aspects of ease, interest, and efficiency.

\section{Research Method:-}

The type of research to be carried out is research and development. Research and Development (R \& D) is the term commonly used to describe the activities undertaken by firms and other entities in order to create new or improved products and processes [17]. The research development of this teacher's book uses the Plomp development model. The Plomp development model consists of three stages: preliminary research, prototyping phase and assessment phase. The purpose of this study is to determine the practicality of the Integrated Science teacher book with the theme of blood fluid using integrated learning integrated type learning integrated 21 st century learning. The object of research is the integrated science teacher book with the blood fluid theme using integrated learning integrated type 21 st learning learning. development stage. The research instrument used was a practicality assessment sheet filled out by a number of science teachers at State Junior High Schools in West Pasaman.

\section{Practicality analysis using a Likert Scale is done by the steps:}

1. Give a score for each answer item strongly agree (4), agree (3), disagree (2), strongly disagree (1)

2. Add up the total score for each practitioner for all indicators.

3. Grading practicality by using the formula:

$P=\frac{f}{N} x 100 \%$

Information:

$P \quad$ : Final value

$f \quad$ : Score acquisition

$N \quad$ : Maximum score

The Practicality category can be seen in Table 1 .

Table 1:-Practicality Categories

\begin{tabular}{|c|c|c|}
\hline No & Value & Criteria \\
\hline 1 & $80 \%<\mathrm{x} \leq 100 \%$ & Very practical \\
\hline 2 & $60 \%<\mathrm{x} \leq 80 \%$ & Practical \\
\hline 3 & $40 \%<\mathrm{x} \leq 60 \%$ & Quite Practical \\
\hline 4 & $20 \%<\mathrm{x} \leq 40 \%$ & Less Practical \\
\hline 5 & $0 \%<\mathrm{x} \leq 20 \%$ & Not practical \\
\hline
\end{tabular}


Source: Modified from Riduwan [18]

The teacher book that was developed was declared practical if the average practicality values obtained from the practicality assessment sheet were in the range of 61-80 and declared very practical if the average practicality values were in the range of 81-100.

\section{Results and Discussion:-}

Before the practicality test of the teacher's book is conducted, the validity of the teacher's practicality instrument is done first. The results of the teacher's practicality assessment instrument are further presented in Table 2.

Table 2:-Results of Analysis of the Validity of Teacher's Book Practicality Instruments

\begin{tabular}{|c|l|c|}
\hline No & \multicolumn{1}{|c|}{ Aspect } & Value \\
\hline 1 & The effectiveness instrument is able to measure the effectiveness of teacher's books & 0,67 \\
\hline 2 & The instrument has clear usage instructions & 0,89 \\
\hline 3 & The instrument is easy to use in the assessment process & 0,89 \\
\hline 4 & $\begin{array}{l}\text { The instrument is able to measure the increase in teacher knowledge after using the teacher's } \\
\text { book. }\end{array}$ & 0,78 \\
\hline 5 & $\begin{array}{l}\text { The instrument is able to measure the improvement of teacher skills after using the teacher's } \\
\text { book }\end{array}$ & 0,67 \\
\hline 6 & $\begin{array}{l}\text { The instrument can measure the ease with which teachers carry out the learning process when } \\
\text { using teacher books }\end{array}$ & 0,67 \\
\hline 7 & The instrument has feedback on the results of the assessment & 0,67 \\
\hline 8 & The size and type of writing the instrument can be read clearly & 1,00 \\
\hline 9 & The instrument display is arranged systematically & 1,00 \\
\hline 10 & Display how to write instruments consistently & 1,00 \\
\hline & Average & 0,82 \\
\hline
\end{tabular}

From Table 2 it can be seen that the validity value of the teacher's practicality instrument obtained a validity value of 0.82 with a valid category, meaning that the practicality instrument is precisely used to determine the practicality of the teacher's book.

The practicality test of the teacher's book is carried out in three stages namely; one-on-one test, small group test and field test. The practicality of the teacher's book that was developed consisted of aspects of ease, interest, and efficiency. Indicators from all three aspects can be seen in Table 3.

Table 3:-Indicators of Practicality Aspects

\begin{tabular}{|c|c|c|}
\hline No & Aspect & Indicator \\
\hline \multirow[t]{8}{*}{1} & \multirow[t]{8}{*}{ Convenience } & $\begin{array}{l}\text { Teacher's book material makes it easy for teachers to find the principles of science in } \\
\text { everyday life. }\end{array}$ \\
\hline & & $\begin{array}{l}\text { Learning activities in the teacher's book can facilitate the teacher in carrying out } \\
\text { learning activities. }\end{array}$ \\
\hline & & $\begin{array}{l}\text { The assessment instructions in the teacher's book make it easier for the teacher to carry } \\
\text { out the assessment. }\end{array}$ \\
\hline & & Integrated learning steps make it easy for teachers to carry out learning activities. \\
\hline & & $\begin{array}{l}\text { Alternative answers in the teacher's book make it easy for the teacher to make an } \\
\text { assessment. }\end{array}$ \\
\hline & & $\begin{array}{l}\text { The pictures presented in the teacher's book make it easy for the teacher to explain the } \\
\text { application of the concept of science to students. }\end{array}$ \\
\hline & & $\begin{array}{l}\text { The answer key in the teacher's book makes it easy for the teacher to carry out the } \\
\text { assessment. }\end{array}$ \\
\hline & & the concept map in the teacher's book makes it easy for the teacher to understand the \\
\hline
\end{tabular}




\begin{tabular}{|c|c|c|}
\hline & & integration of science material on the theme of blood fluid. \\
\hline \multirow[t]{5}{*}{2} & \multirow[t]{5}{*}{ Interesting } & The color composition in the teacher's book is interesting to see. \\
\hline & & $\begin{array}{l}\text { The integration of the material in the teacher's book makes the teacher happy to teach } \\
\text { science. }\end{array}$ \\
\hline & & The completeness of the material in the teacher's book adds to the teacher's insight. \\
\hline & & The activities in the teacher's book make the teacher motivated to teach. \\
\hline & & The pictures presented in the teacher's book add to the teacher's motivation to read it. \\
\hline \multirow[t]{5}{*}{3} & \multirow[t]{5}{*}{ Efficiently } & Requires a short time to understand the integration of the material in the teacher's book. \\
\hline & & $\begin{array}{l}\text { The learning activities in the teacher's book are in accordance with the standard hours } \\
\text { set by the government. }\end{array}$ \\
\hline & & Requires a short time to understand the learning activities in the teacher's book. \\
\hline & & Assessment in the teacher's book can be understood and carried out in a short time. \\
\hline & & The use of teacher's books in the learning process requires a relatively small cost. \\
\hline
\end{tabular}

One-to-one evaluation is done by asking the teacher to comment on the teacher's book that has been designed. The teacher's book was given to three educators who taught Natural Sciences in class VIII junior high school, each had high, medium, and low abilities. This activity is carried out by asking the teacher to read a teacher's book that is valid. The results of the analysis can be seen in Table 4.

Table 4:-Practicality Analysis Results of the One-to-one Evaluation Stage

\begin{tabular}{|c|l|l|}
\hline No & Indicator & Value (\%) \\
\hline 1 & convenience & 75,93 \\
\hline 2 & interesting & 81,67 \\
\hline 3 & efficiently & 76,67 \\
\hline Average & $\mathbf{7 9 , 2 0}$ \\
\hline Category & Practical \\
\hline
\end{tabular}

Based on Table 4 the aspects of convenience get a value of $75.93 \%$, the interesting aspect gets a value of $81.67 \%$, and the efficient aspect gets a value of $76.67 \%$. From the three aspects obtained an average value of $79.20 \%$ with the practical category. For more details, can be seen in Figure 1.

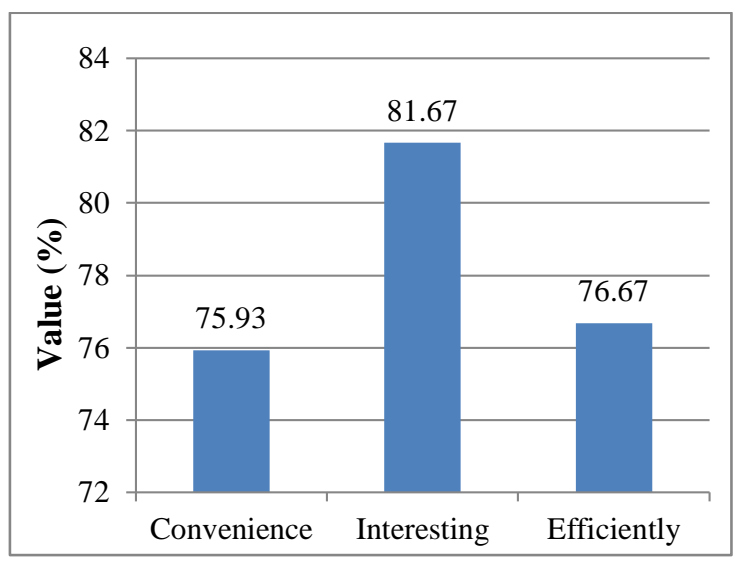

Figure 1:-Graph of the results of the practicality analysis of the One-to-one Evaluation Stage

Based on Figure 1, it can be seen that the practical level of teacher's books on the aspect of ease of obtaining the lowest score, this is because the concept map does not facilitate teachers in understanding the integration of natural science material on the theme of blood fluid. Based on this analysis a revision was made on the concept map. Prototypes are developed, evaluated, and revised repeatedly to obtain a valid and practical prototype [19]. Revisions at the one-to-one evaluation stage can be seen in Figure 2. 


\section{PETA KONSEP}

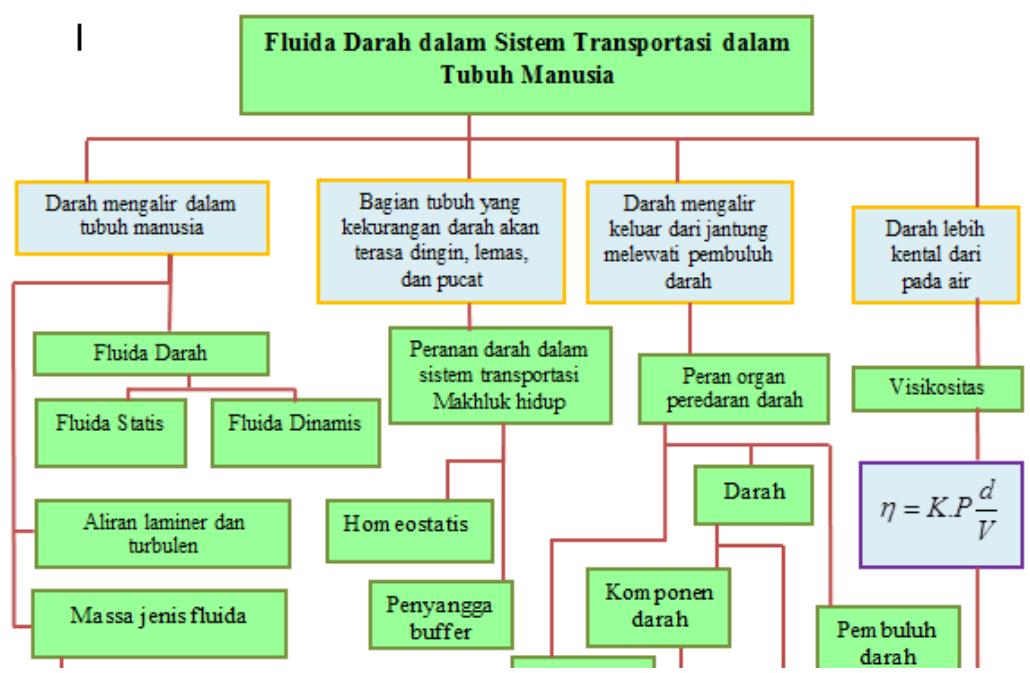

(a)

\section{PETA KONSEP}

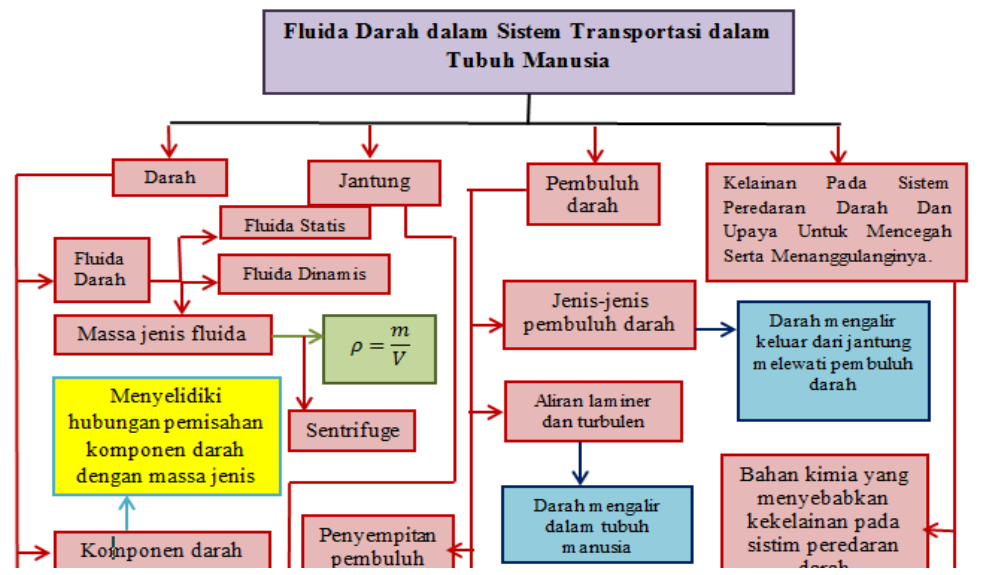

(b)

Figure 2:-Before revision (a), after revision (b)

After the revision, the small group evaluation continues.

In the evaluation stage the small group of researchers conducted a trial on 6 teachers. The activities carried out at this stage are teachers using integrated science teacher books with the theme of connected type integrated blood fluid learning in the 21st century in learning in their respective schools and students using integrated science student books with the connected type blood fluid integrated learning 21 st century learning. conducted during one meeting. The results of the analysis can be seen in Table 6 .

Table 6:-Small Group Evaluation Stage

\begin{tabular}{|c|l|l|}
\hline No & Indicator & Value (\%) \\
\hline 1 & convenience & 78,13 \\
\hline 2 & interesting & 83,33 \\
\hline 3 & efficiently & 85,83 \\
\hline Average & $\mathbf{8 1 , 6 0}$ \\
\hline Category & Very Practical \\
\hline
\end{tabular}


For more details, can be seen in Figure 3.

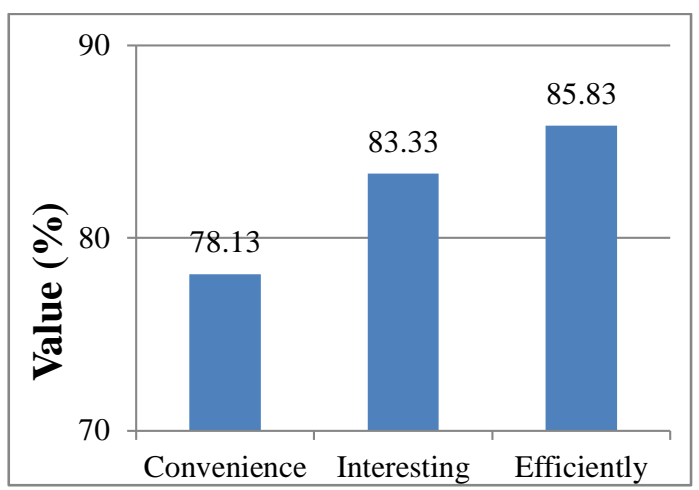

Figure 3:-Graph of the results of the practicality analysis of the Small Group Evaluation stage

Based on Figure 3, it can be seen that the level of practicality of the teacher's book in the aspect of ease of obtaining an average value of $78.13 \%$ with a practical category, in the interesting aspect obtains an average value of $83.33 \%$ with a very practical category, and in the aspect of efficiency obtains a value of $85,83 \%$. From these data values obtained $81.60 \%$ with a very practical category. The next step taken was field testing

The field test was conducted by asking 9 teachers to use an integrated science teacher's book on the theme of blood fluid using 21st century connected type integrated learning in their respective schools, while students use an integrated science student's book with a blood fluid theme using integrated 21st century connected type learning. This activity was carried out during three meetings. The results of the analysis can be seen in Table 7.

Table 7:-Results of the Field Tests Practicality Analysis Results

\begin{tabular}{|c|l|l|}
\hline No & Indicator & Value (\%) \\
\hline 1 & convenience & 79,94 \\
\hline 2 & interesting & 86,11 \\
\hline 3 & efficiently & 87,22 \\
\hline Average & $\mathbf{8 4 , 4 2}$ \\
\hline Category & Very Practical \\
\hline
\end{tabular}

For more details, see figure 4.

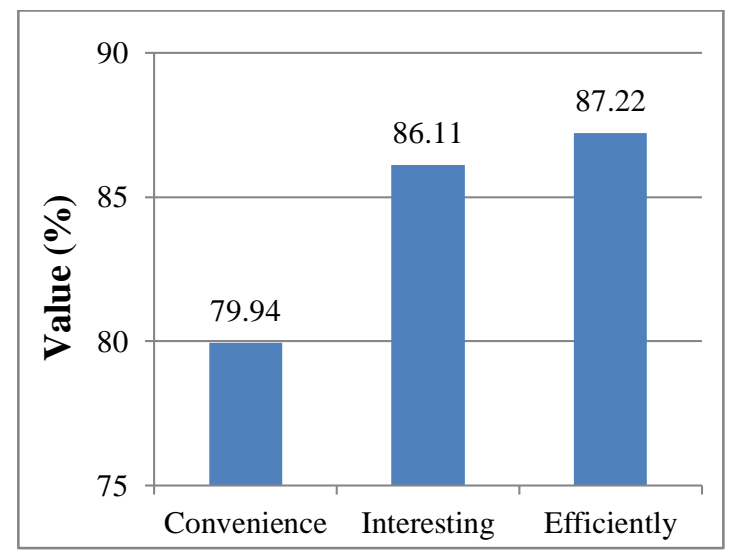

Figure 4:-Graph of the results of the practicality analysis of the field tests stage

Based on Figure 4 it can be seen that the practical level of teacher's books on the aspect of ease of obtaining an average value of $79.94 \%$ with a very practical category, on the interesting aspect of getting an average rating of $86.11 \%$ with a very practical category, and on the aspect of efficiency obtains a value of $87,22 \%$ with a very practical category. Based on these data the practicality value of 85.35 was obtained with a very practical category. Through the field test the teacher's book was obtained with a very practical kategoro, this is because the teacher's 
book is very easy to use in learning, and requires little cost and time in its use. Practicality shows the level of ease of use and implementation which includes the cost and time in implementing and managing and interpreting the results $[15]$.

\section{Conclusion:-}

Based on the analysis results, the teacher book that has been developed already meets one of the qualities of product development, where the results of the practicality analysis obtained a value of 84.42 with a very practical category. This means that the integrated science teacher's book on the theme of blood fluid using integrated types of learning in the 21 st century is very practical in aspects of convenience, learning, and efficiency. Thus the teacher's book is very practical to be used in the learning process of science in schools.

\section{References:-}

1. Ditasari, Rahma. (2013). Pengembangan Modul Pembelajaran IPA Terpadu Berpendekatan Keterampillam Proses Pada Tema Dampak Limbah Rumah Tangga Terhadap Lingkungan. UNNES Science Educational Journal. USEJ Vol 2.

2. Prastowo, Andi. (2014). Pengembangan Bahan Ajar Tematik. Jakarta: Kencana..

3. Trianto. 2014. Model Pembelajaran Terpadu. Jakarta: Bumi Aksara.

4. Fogarty, R \& Brian M. Pete. (2009). How to Integrate the Curricula, Third Edition. Thousand Oaks, CA, New Delhi, London and Singapore: Sage.

5. Ulfa, Anik. dkk. (2013). Pengembangan LKS IPA Berbasis Word Square Model Keterpaduan Connected. Unnes Science Education Journal, 2(1), 239-244.

6. Kunandar. (2013). Penilaian autentik (penilaian hasil belajar peserta didik berdasarkan kurikulum 2013). Jakarta: PT.Raja Grafindo Persada Prastowo, Andi. 2014. Pengembangan Bahan Ajar Tematik. Jakarta: Kencana.

7. R Helfira, Ratnawulan, and Gusnedi . (2019). Analysis of Integrated Science Textbook Teachers with Blood Fluid Themes by Using Integrated Learning Connected Type Integrated Learning 21st Century. Journal of Physics, 1185(1), 1742-6596.

8. Faridah, Norlaila Mufti, Rozmel Abdul Latiff \& Maryam Mohamed Amin. (2011). Project-Based Learning $(\mathrm{PjBl})$ : inculcating sift skills in 21st Century Workplace. International Procedia-Sosial and Behavioral Science, 59, 565-573.

9. Zain Ismail Md .(2017). The Collaborative Instructional Design System (CIDS): Visualizing the 21st Century Learning Universal. Journal of Educational Research, 5 (12), 2259-2266

10. Levin J .(2012). Teaching Generation TechX with the 4Cs: Using Technology to Integrate 21st Century Skills. Journal of Instructional Research, 1, $59-64$.

11. Oludipe, Daniel Idowu. (2011). Developing Nigerian Integrated Science Curriculum. Journal of Soil Science and Environmental Management, 2(8), 134-145. (accessed 08 juni 2018)

12. Febrilla, Ratnawulan, and Usmeldi. (2019). Validity Of Integrated Natural Science Teacher's Book With Immersed Type That Contain Character On Subject Of Bioelectrical Energy By Using Science Process Skills Approach. Journal of Physics, 1185 (1), 1742-6596.

13. Ilham Dani, Ratnawulan, and Syafriani .(2019) Needs Analysis in teacher book development Integrated Natural Science type connected character charged with the theme of the sense of hearing and the sonar system of living things. Journal of Physics, 1185 (1), 1742-6596.

14. Zubaidah, Siti dkk. (2014). Buku Guru Ilmu Pengetahuan Alam SMP/MTs kelas VIII. Jakarta: Kementerian Pendidikan dan Kebudayaan.

15. Arikunto, Suharsimi. (2008). Dasar-dasar Evaluasi Pendidikan. Jakarta: Bumi Aksara.

16. Arman. C, C Arman, A Fauzi and H Rifai. (2019). Practicalities in the development of integrated science textbook of junior high school drought theme using problem based learning. Journal of Physics, 1185(1), 17426596.

17. Hall, Bronwyn H. 2006. Contribution to the International Encyclopedia of the Social Sciences, second edition.

18. Riduwan. (2012). Metode dan Teknik Menyusun Proposal Penelitian. Bandung: Alfabeta

19. Plomp. (2013). Educational Design Research: An Introduction, Educational Research Part A An Introduction. Enschede, Netherland : National Institute for Curriculum Development. 